\title{
PROCESSING CHAINS FOR DESIS AND ENMAP IMAGING SPECTROSCOPY DATA: SIMILARITIES AND DIFFERENCES
}

\author{
T. Storch ${ }^{*}$ and R. Müller \\ German Aerospace Center (DLR), Earth Observation Center (EOC), Münchner Str. 20, 82234 Weßling, Germany \\ (tobias.storch, rupert.mueller)@dlr.de
}

Commission I, WG I/1

KEY WORDS: processing chain, imaging spectroscopy, DESIS, EnMAP, satellite mission

\begin{abstract}
:
The Earth Observation Center (EOC) of the German Aerospace Center (DLR) realizes operational processors for DESIS (DLR Earth Sensing Imaging Spectrometer) and EnMAP (Environmental Mapping and Analysis Program) high-resolution imaging spectroscopy remote sensing satellite missions. DESIS is planned to be launched in 2018 and EnMAP in 2020. The developmental (namely schedule, deployment, and team) and functional (namely processing levels, algorithms in processors, and archiving approaches) similarities and differences of the fully-automatic processors are analyzed. The processing chains generate high-quality standardized image products for users at different levels taking characterization and calibration data into account. EOC has long lasting experiences with the airborne and spaceborne acquisition, processing, and analysis of hyperspectral image data. It turns out that both activities strongly benefit from each other.
\end{abstract}

\section{INTRODUCTION}

The Earth Observation Center (EOC) of the German Aerospace Center (DLR) realizes operational processors for

- DESIS (DLR Earth Sensing Imaging Spectrometer) and

- EnMAP (Environmental Mapping and Analysis Program) high-resolution imaging spectroscopy remote sensing satellite missions (see Table 1 and Figure 1 for an illustration of their orbits). DESIS is planned to be launched in 2018 and EnMAP in 2020. The developmental (namely schedule, deployment, and team) and functional (namely processing levels, algorithms in processors, and archiving approaches) similarities and differences of the fully-automatic processing chains are analyzed (see Figure 2). The processing chains generate highquality standardized image products for users at different levels taking characterization and calibration data into account. EOC has long lasting experiences with the airborne and spaceborne acquisition, processing, and analysis of hyperspectral image data. It turns out that both developments strongly benefit from each other (Storch et al., 2013a).

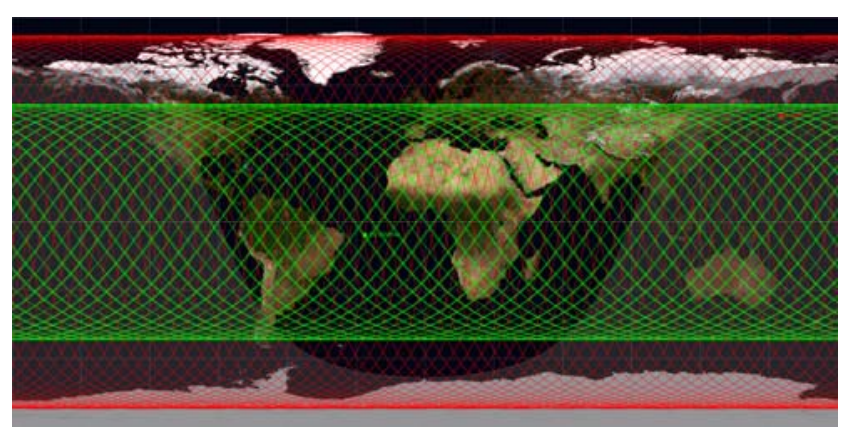

Figure 1. DESIS (green) and EnMAP (red) orbits for four days

\subsection{DESIS}

DESIS (Müller et al., 2015) is a scientific and commercial hyperspectral mission developed and integrated in the MultiUser-System for Earth Sensing (MUSES) platform installed on the International Space Station (ISS). The instrument DESIS is developed by DLR and delivered to TBE (Teledyne Brown Engineering, located in Huntsville, Alabama, USA) for integration into MUSES. The publically traded company TBE develops and operates the MUSES platform with four instrument compartments, whereas DLR provides the Software processors for the DLR Ground Segment and the TBE Ground Segment.

\subsection{EnMAP}

EnMAP (Guanter et al., 2015) is a scientific mission for measuring, deriving, and analyzing diagnostic parameters, which describe vital processes on the Earth's surface encompassing agriculture, forestry, soil and geological environments, as well as coastal zones and inland waters. Open access to all products will be granted to the international user community. The imaging spectrometer consists of two 2dimensional detector arrays, one for Visible and Near InfraRed (VNIR) and one for ShortWave InfraRed (SWIR). The DLR is responsible for the establishment and operation of the complete ground segment including calibration activities. The space segment is realized by OHB System AG.

\section{METHODOLOGY}

We first consider the developmental, namely schedule and contractual, and second the functional similarities and differences between the processing chains for DESIS and EnMAP imaging spectroscopy data (Storch et al., 2013b).

\footnotetext{
${ }^{*}$ Corresponding author
} 


\begin{tabular}{|c|c|c|}
\hline $\begin{array}{l}\text { Mission } \\
\text { Instrument }\end{array}$ & $\begin{array}{l}\text { ISS/MUSES } \\
\text { DESIS }\end{array}$ & $\begin{array}{l}\text { EnMAP } \\
\text { HSI ( } 2 \text { instr.) }\end{array}$ \\
\hline Space agency & $\begin{array}{l}\text { DLR, Germany \& } \\
\text { Teledyne, USA }\end{array}$ & DLR, Germany \\
\hline Target lifetime & $2018-2023$ & $2020-2025$ \\
\hline $\begin{array}{l}\text { Satellite (mass, } \\
\text { dimension of } \\
\text { main body) }\end{array}$ & $\begin{array}{l}455 \mathrm{t}, \\
109.0 \times 97.9 \times 27.5 \mathrm{~m}^{3} \\
\text { (multi-purpose) }\end{array}$ & $\begin{array}{l}1 \mathrm{t}, \\
3.1 \times 2.0 \times 1.7 \mathrm{~m}^{3} \\
(\text { single-purpose) }\end{array}$ \\
\hline $\begin{array}{l}\text { Orbit (type, } \\
\text { local time at } \\
\text { equator, } \\
\text { inclination, } \\
\text { hight, period, } \\
\text { repeat cycle) }\end{array}$ & $\begin{array}{l}\text { not } \\
\text { synchronous, } \\
\text { various, } 51.6^{\circ} \text {, } \\
320 \mathrm{~km} \text { to } 430 \mathrm{~km} \text {, } \\
93 \mathrm{~min} \text {, no repeat } \\
\text { cycle }\end{array}$ & $\begin{array}{l}\text { Sun-synchronous, } \\
11: 00, \quad 98.0^{\circ} \text {, } \\
653 \mathrm{~km}, 98 \mathrm{~min} \text {, } \\
398 \text { revolutions in } \\
27 \text { days }\end{array}$ \\
\hline $\begin{array}{l}\text { Off-nadir } \\
\text { pointing } \\
\text { (across-track, } \\
\text { along-track) }\end{array}$ & $\begin{array}{l}-45^{\circ} \text { (backboard) to } \\
+5^{\circ} \text { (starboard), } \\
-40^{\circ} \text { to }+40^{\circ} \\
\text { (by MUSES and } \\
\text { DESIS) }\end{array}$ & $\begin{array}{l}-30^{\circ} \text { to }+30^{\circ}, \\
0^{\circ} \\
\text { (by EnMAP) }\end{array}$ \\
\hline $\begin{array}{l}\text { Pointing } \\
\text { Knowledge }\end{array}$ & $30 \mathrm{~m}$ (w GCPs) & $\begin{array}{l}100 \mathrm{~m} \text { (w/o GCPs), } \\
30 \mathrm{~m} \text { (w GCPs) }\end{array}$ \\
\hline Coverage & $55^{\circ} \mathrm{N}$ to $52^{\circ} \mathrm{S}$ & $74^{\circ} \mathrm{N}$ to $74^{\circ} \mathrm{S}$ \\
\hline $\begin{array}{l}\text { Revisit } \\
\text { frequency }\end{array}$ & $\begin{array}{l}3 \text { to } 5 \text { days } \\
\text { (average) }\end{array}$ & $\begin{array}{l}\leq 4 \text { days, } \leq 27 \text { days } \\
\left(-5^{\circ} \text { to }+5^{\circ} \text { pointing }\right)\end{array}$ \\
\hline $\begin{array}{l}\text { Instrument } \\
\text { (mass) }\end{array}$ & $93.2 \mathrm{~kg}$ & $350 \mathrm{~kg}$ \\
\hline $\begin{array}{l}\text { BRDF } \\
\text { (bidirectional } \\
\text { reflectance } \\
\text { distribution } \\
\text { function) }\end{array}$ & $\begin{array}{l}\text { yes } \\
(11 \text { measurements } \\
\text { between }-15^{\circ} \text { and } \\
\left.+15^{\circ} \text { in steps of } 3^{\circ}\right)\end{array}$ & no \\
\hline $\begin{array}{l}\text { Spatial } \\
\text { resolution }\end{array}$ & 30 m (@400km) & $30 \mathrm{~m}$ \\
\hline Swath & 30km (@ 400km) & $30 \mathrm{~km}$ \\
\hline Spectral range & $420 \mathrm{~nm}$ to $1000 \mathrm{~nm}$ & $420 \mathrm{~nm}$ to $2450 \mathrm{~nm}$ \\
\hline $\begin{array}{l}\text { Spectral } \\
\text { sampling }\end{array}$ & $2.55 \mathrm{~nm}$ & $\begin{array}{l}6.5 \mathrm{~nm} \text { (VNIR), } \\
10 \mathrm{~nm} \text { (SWIR) }\end{array}$ \\
\hline $\begin{array}{l}\text { Spectral } \\
\text { accuracy }\end{array}$ & na & $\begin{array}{l}0.5 \mathrm{~nm} \text { (VNIR), } \\
1.0 \mathrm{~nm} \text { (SWIR) }\end{array}$ \\
\hline $\begin{array}{l}\text { Spectral } \\
\text { resolution }\end{array}$ & $\begin{array}{l}235 \text { bands (no bin.), } \\
58 \text { bands ( } 4 \text { bin.) }\end{array}$ & $\begin{array}{l}94 \text { bands (VNIR), } \\
134 \text { bands (SWIR) }\end{array}$ \\
\hline $\begin{array}{l}\text { SNR (signal-to- } \\
\text { noise-ratio) }\end{array}$ & $\begin{array}{l}205 \text { (no bin.) / } 406 \\
\text { (4 bin.) @ } 550 \mathrm{~nm}\end{array}$ & $\begin{array}{l}500 @ 495 \mathrm{~nm} \\
150 @ 2200 \mathrm{~nm}\end{array}$ \\
\hline $\begin{array}{l}\text { Smile \& } \\
\text { Keystone } \\
\end{array}$ & $\begin{array}{l}\text { Smile }<1.7 \text { pixel } \\
\text { Keystone }<0.3 \text { pixel }\end{array}$ & $<0.2$ pixel \\
\hline $\begin{array}{l}\text { Radiometric } \\
\text { resolution }\end{array}$ & $\begin{array}{l}12 \text { bit plus } 1 \text { bit } \\
\text { (low gain/high gain) }\end{array}$ & 14 bit \\
\hline $\begin{array}{l}\text { Radiometric } \\
\text { accuracy }\end{array}$ & na & $5 \%$ \\
\hline $\begin{array}{l}\text { On-board } \\
\text { calibration }\end{array}$ & $\begin{array}{l}\text { dark signal } \\
\text { (before/after acq.), } \\
\text { detector LEDs }\end{array}$ & $\begin{array}{lr}\text { dark } & \text { signal } \\
\text { (before/after } & \text { acq.), } \\
\text { detector } & \text { LEDs, } \\
\text { doped spectralon, } & \text { sper } \\
\text { integrating } & \text { sphere, } \\
\text { full } & \text { aperture } \\
\text { diffuser } & \end{array}$ \\
\hline $\begin{array}{l}\text { Capacity (per } \\
\text { day, storage, } \\
\text { downlink) }\end{array}$ & $\begin{array}{l}2360 \mathrm{~km} \text { per day, } \\
225 \text { GBit, } \\
\text { Ku-band }\end{array}$ & $\begin{array}{l}5000 \mathrm{~km} \text { per day, } \\
512 \text { GBit, } \\
\text { X-band }\end{array}$ \\
\hline $\begin{array}{l}\text { Processing } \\
\text { levels }\end{array}$ & $\begin{array}{l}\text { L1A (archived), } \\
\text { L1B, L1C, L2A }\end{array}$ & $\begin{array}{l}\text { L0 (archived), L1B, } \\
\text { L1C, L2A }\end{array}$ \\
\hline
\end{tabular}
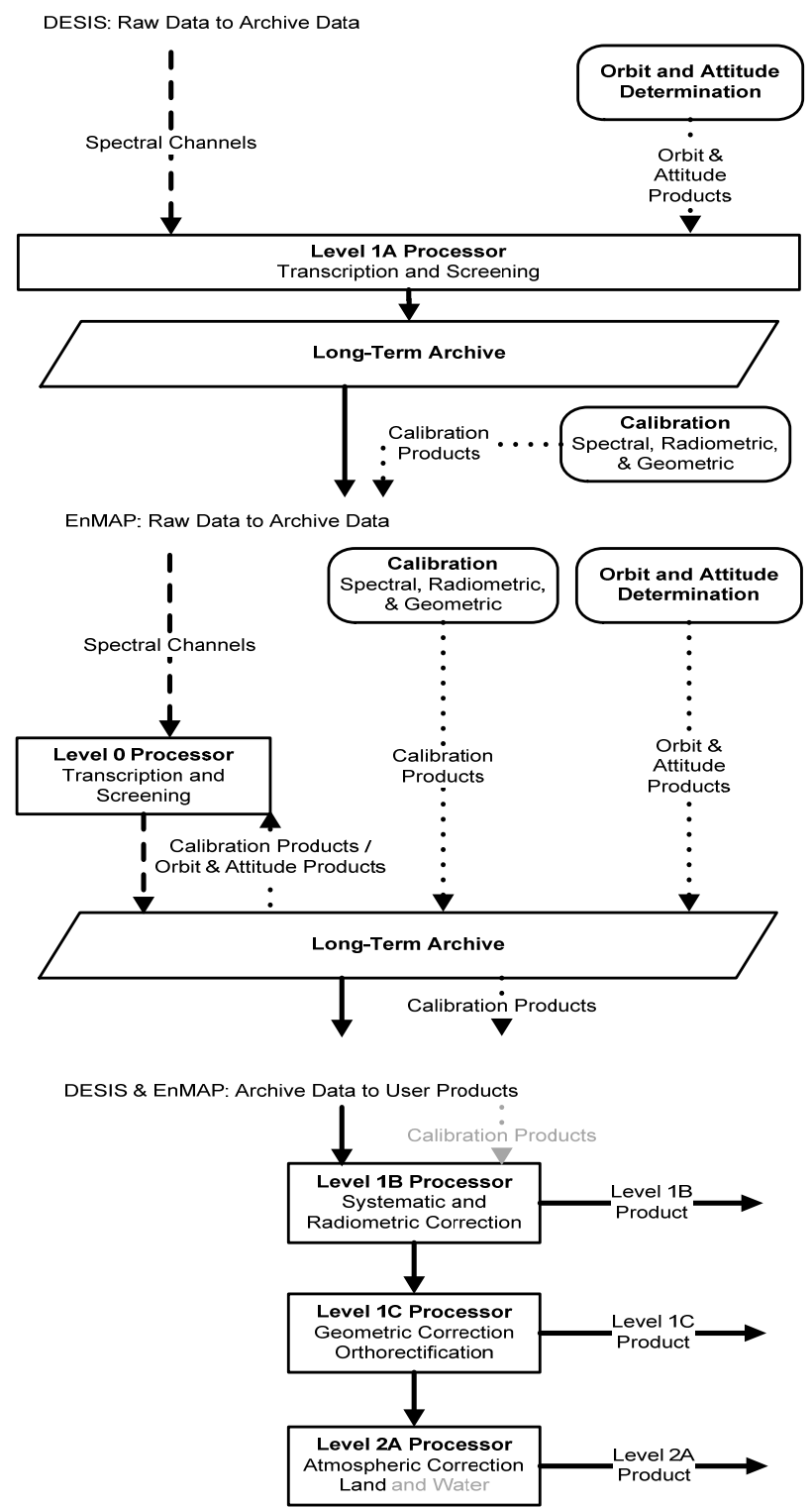

Figure 2. Image Processing Chains

\section{RESULTS AND VALIDATION}

\subsection{Developmental Aspects}

3.1.1 Schedule: The processing chains for DESIS and EnMAP are similarly in their production, verification, and validation phases. Because the instruments are also in production, the development of the processors is based on simulated data and analyses. This increases the risks and efforts compared to the development based on existing data and analyses. But it also gives the opportunity to suggest changes on the instrument (or even the platform) and to be operational in best time. 
3.1.2 Deployment: The DESIS processors shall be deployed at two sites: one at Teledyne and one at DLR, whereas the EnMAP processors shall be deployed at one site: at DLR. As a result (see Figure 1): DESIS Level 1A products are generated and archived at Teledyne from where DLR orders products for ingestion into the DLR archive. Higher-level product generation is performed at both sites, but sharing the same calibration tables as part of the processors. EnMAP archives Level 0 products and thus, for higher-level product generation, in case, improved auxiliary data are applied.

3.1.3 Team: Finally, the associated teams and corresponding shifts allow for more flexibility during critical project phases and intensive exchanges of experiences for not expected situations.

\subsection{Functional Aspects}

Both processors are fully automatic and separate acquisitions into tiles of $1024 \times 1024$ pixels in order to simplify the data handling also on end users' site. However, information relevant to or based on the complete acquisition is annotated to each archived product. Even similar data quality routines and product formats are applied also to ease the combined use of products from DESIS and EnMAP (Kerr et al. 2016) (Müller et al. 2010).

3.2.1 Level 1B: Level 1B processors perform systematic and radiometric corrections and have a similarity of approx. $20 \%$. Even if some processing steps are comparable (e.g. defective pixel flagging, non-linearity correction, dark signal correction, gain matching, and spectral/radiometric referencing), different calibration equipment lead to differences in the correction approaches or in their sequence.

One major difference is that DESIS applies a rolling-shutter, namely each spectral line is acquired at a slightly different time. This results in less qualitative spectra compared to a globalshutter especially in heterogeneous regions with dominant absorption features, but a higher signal-to-noise ratio (SNR) is achieved. Rolling shutter, smile, and keystone correction is performed in L1B within one resampling step. Experimental products are acquired with global shutter mode, but with a reduced along track spatial resolution of $60 \mathrm{~m}$.

Another major difference is that EnMAP additionally considers stray light effects based on spatially and spectrally neighbouring pixels as well as stray light from out of field-ofview.

3.2.2 Level 1C: Level 1C processors perform orthorectification have a similarity of approx. 90\%. Both instruments are push-broom sensors with similar spatial resolutions, swaths, and off-nadir pointing capabilities. Orbit and attitude data are based on GPS (global positioning system) and STS (star tracker system) and IMU (Inertial Measurement Unit). Image matching techniques to enhance the sensor model for improved relative geo-location accuracy are used. The further steps (beside direct georeferencing) of orthorectification such as DEM (digital elevation model) intersection, map projection, and resampling are equal.

One major difference is that EnMAP contains two instruments, one for the VNIR (420 nm to $1000 \mathrm{~nm}$ ) and one for the SWIR (900 $\mathrm{nm}$ to $2450 \mathrm{~nm}$ ) spectral range. The in-field separation leads to a divergence angle of about 3.16 arc min which corresponds to about $600 \mathrm{~m}$ on ground. They are co-registered by considering all channels of both spectral ranges separately.
3.2.3 Level 2A: Level 2A processors perform atmospheric compensation over land have a similarity of approx. $70 \%$. Many steps are comparable (e.g. generation of masks (landwater, haze-cloud-shadow), retrieval of aerosol optical thickness (AOT), retrieval of columnar water vapour, retrieval of surface reflectances) but with an improved accuracy for EnMAP making use of its wider spectrum compared to DESIS for the determination of the AOT (applying a channel at $2.1 \mu \mathrm{m}$ beside channels at $0.66 \mu \mathrm{m}$ and $0.47 \mu \mathrm{m}$ ) or cirrus (applying a channel at $1.38 \mu \mathrm{m}$ ). Due to budgetary constraints DESIS does not apply a dedicated atmospheric correction over water.

\section{CONCLUSIONS}

The paper illustrated the functional similarities and differences between DESIS and EnMAP with a focus on the processing chains, where all-over approx. $60 \%$ are similar. It turned out that not only the functional but also development aspects have to be taken into account when investigating synergies between realizations

\section{ACKNOWLEDGEMENTS}

Supported by the DLR Space Administration with funds of the German Federal Ministry of Economic Affairs and Technology on the basis of a decision by the German Bundestag (50 EE 0850).

\section{REFERENCES}

Guanter, L., Kaufmann, H., Segl, K., Förster, S., Rogass, C., Chabrillat, S., Küster, T., Hollstein, A., Rossner, G., Chlebek, C., Straif, C., Fischer, S., Schrader, S., Storch, T., Heiden, U., Müller, A., Bachmann, M., Mühle, H., Müller, R., Habermeyer, M., Ohndorf, A., Hill, J., Buddenbaum, H., Hostert, P., van der Linden, S., Leitao, P.J., Rabe, A., Doerffer, R., Krasemann, H., Xi, H., Mauser, W., Hank, T., Locherer, M., Rast, M., Staenz, K. and Sang, B., 2015. The EnMAP Spaceborne Imaging Spectroscopy Mission for Earth Observation. Remote Sensing, 7(7), pp. 8830-8857.

Kerr, G.H.G., Avbelj, J., Carmona, E., Eckardt, A., Gerasch, B., Graham, L., Günther, B., Heiden, U., Krutz, D., Krawczyk, H., Makarau, A., Miller, R., Müller, R., Perkins, R. and Walter, I., 2016. The Hyperspectral sensor DESIS on MUSES: processing and application. Proceedings of IEEE International Geoscience and Remote Sensing Symposium (IGARSS) 2016, IEEE Xplore, pp. 268-271. IGARSS 2016, 10-15 July 2016, Beijing, China.

Müller, R., Bachmann, M., de Miguel, A., Müller, A., Neumann, A., Palubinskas, G., Richter, R., Schneider, M., Storch, T., Walzel, T., Kaufmann, H., Guanter, L., Segl, K., Heege, T. and Kiselev, V., 2010. The Processing Chain and $\mathrm{Cal} / \mathrm{Val}$ Operations of the Future Hyperspectral Satellite Mission EnMAP. IEEE Aerospace Conferences 2010, pp. 1-9. IEEE Aerospace Conference 2010, 6-13 March 2010, Big Sky, Montana, USA

Müller, R., Avbelj, J., Carmona, E., Gerasch, B., Graham, L., Günther, B., Heiden, U., Kerr, G., Knodt, U., Krutz, D., Krawczyk, H., Makarau, A., Miller, R., Perkins, R. and Walter, I., 2015. The new hyperspectral sensor DESIS on the multipayload platform MUSES installed on the ISS. The International Archives of the Photogrammetry, Remote Sensing and Spatial Information Sciences, XLI-B1, pp. 461-467. XXIII ISPRS Congress, 12-19 July 2016, Prague, Czech Republic. 
Storch, T., Habermeyer, M., Eberle, S., Mühle, H. and Müller, R., 2013a. Towards a Critical Design of an Operational Ground Segment for an Earth Observation Mission. Journal of Applied Remote Sensing, 7(1), pp. 1-12.

Storch, T., Schwind, P., Palubinskas, G., Müller, R., Schneider, M., Reinartz, P., Chlebek, C. and Gascon, F., 2013b. Image Processing Chains for ALOS and EnMAP Data: Similarities and Differences. Proceedings of the ESA Living Planet Symposium 2013, SP-722, pp. 1-5. ESA Living Planet Symposium 2013, 9-13 September 2013, Edinburgh, UK. 